\title{
15. SEISMIC PROPERTIES OF SHEETED DIKES FROM HOLE 504B, ODP LEG $111^{1}$
}

\author{
N. I. Christensen, W. W. Wepfer, and R. D. Baud ${ }^{2}$
}

\begin{abstract}
Seismic velocities have been measured at confining pressures to $600 \mathrm{MPa}$ for eight samples of sheeted dike rock obtained from Hole 504B during Leg ODP 111. The compressional- and shear-wave velocities are, in general, higher than the velocities measured in overlying dike rocks obtained from the hole during DSDP Leg 83 . The velocity gradients observed in Layer $2 \mathrm{C}$ result from decreasing porosity with depth and increasing metamorphic grade. The laboratory-measured velocities of the Leg 111 dike rocks are similar to those of dike rocks reported for the Bay of Islands, Samail, and Troodos ophiolites.
\end{abstract}

\section{INTRODUCTION}

For over three decades, seismic-refraction studies have provided structural and compositional information on the nature of the oceanic crust in terms of velocity-depth relationships. Early three-layer models (e.g., Raitt, 1963) have evolved into detailed velocity-depth functions that commonly include velocity gradients in place of abrupt discontinuities (e.g., Kempner and Gettrust, 1982). Detailed studies of the velocity structure of ophiolites (e.g., Salisbury and Christensen, 1978) support gradient models and provide a basis for the interpretation of refraction velocities in terms of petrology. Hole 504B, the deepest penetration to date into the ocean crust, sampled sheeted dike rocks that, based on logging velocities, comprise Layer $2 \mathrm{C}$ (e.g., Salisbury et al., 1985). Deep Sea Drilling Project (DSDP) Leg 83 cored approximately $300 \mathrm{~m}$ of sheeted dikes (Anderson, Honnorez, et al., 1985) and Ocean Drilling Program (ODP) Leg 111 cored an additional $212 \mathrm{~m}$ to a total depth of $1562 \mathrm{~m}$ below seafloor at this site.

The recovery of sheeted dikes at the depth of Layer $2 \mathrm{C}$ lends strong support to oceanic crustal ophiolite models and provides valuable samples for physical-property studies. In this paper, we present densities, elastic constants, and seismic velocities as a function of confining pressure for eight dike samples recovered during Leg 111. The laboratory measurements of velocities and densities are compared with similar measurements on sheeted dike rocks from the Bay of Islands, Samail, and Troodos ophiolites.

\section{EXPERIMENTAL METHODS}

Compressional- and shear-wave velocities $\left(\mathrm{V}_{p}\right.$ and $\mathrm{V}_{s}$, respectively) were measured at confining pressures to $600 \mathrm{MPa}$ using the pulse transmission method of Birch $(1960,1961)$. Minicores were taken perpendicular to the drill core (horizontal relative to the surface), cut to right circular cylinders, and polished flat and parallel to within $0.008 \mathrm{~cm}$. Typical sample dimensions after preparation are $2.54 \mathrm{~cm}$ both in length and diameter. Dry- and wet-bulk densities were determined, the latter of which are given in Table 1, and from these values the bulk porosities were calculated. The velocities were measured with the rocks saturated. Pore pressure was kept low via a fine-mesh copper screen beneath a copper foil jacket which allowed for pore-fluid migration while the sample was subjected to varying confining pressure. Figure 1 is an example of velocity-pressure data with the curve fit from Wepfer and Christensen

\footnotetext{
${ }^{1}$ Becker, K., Sakai, H., et al., 1989. Proc. ODP, Sci. Results, 111: College Station, TX (Ocean Drilling Program).

2 Department of Earth and Atmospheric Sciences, Purdue University, West Lafayette, IN 47907.
}

(1987) used to interpolate the values of $\mathrm{V}_{p}$ and $\mathrm{V}_{s}$ given in Table 1. These velocities were then used to calculate the following isotropic elastic constants: Poisson's ratio, bulk modulus, and shear modulus. Figure 2 shows $\mathrm{V}_{p}$ and $\mathrm{V}_{s}$ vs. pressure for all eight samples. Only the curve fits are shown in the figure to avoid clutter.

Laboratory studies of the effect of pore pressure on velocities (Christensen, 1984) show that increasing pore pressure lowers dike velocities only a few percent. Thus, unlike for the upper basalt layers, pore-pressure considerations are probably of secondary importance in dike rocks.

The rocks selected for the velocity measurements are relatively fresh, massive basalts with intersertal to subophitic textures. Plagioclase, clinopyroxene, and olivine form up to $10 \%$ phenocrysts in several samples. Subhedral plagioclase constitutes up to $55 \%$ of the groundmass. Clinopyroxene (up to $50 \%$ ) and magnetite (up to $10 \%$ ) are also abundant in the groundmass. The olivine phenocrysts are commonly replaced by talc, smectite, magnetite, and saponite. The groundmass has extremely patchy zones of recrystallization. Some clinopyroxene is replaced by actinolite and chlorite.

Because of the patchy nature of the secondary minerals, estimates of volume abundances are unreliable. Hence, it is difficult to correlate the percentages of alteration products with velocities. Actinolite and chlorite are fast (Christensen and Wilkens, 1982) and are thus likely to increase velocities in regions where they are abundant. In addition, recrystallization will reduce porosity, which, in turn, increases velocities. The trend of increasing core density with depth (Table 1) probably reflects both increasing percentages of relatively fast recrystallization products as well as decreasing porosity.

\section{DISCUSSION}

Velocities measured at elevated pressures are important for estimating the in-situ properties of the sheeted dike rocks. At Layer 2 confining pressures ( 40 to $100 \mathrm{MPa}$ ) the samples studied have similar compressional- and shear-wave velocities, with the exception of Sample 111-504B-152R-1, 50-52 cm (Fig. 2). This sample, which was taken from the vicinity of a chilled margin, has slightly lower velocities than the others because of its glassy matrix. $\mathrm{V}_{p}$ vs. $\mathrm{V}_{s}$ at in-situ pressures is shown in Figure 3, along with lines of constant Poisson's ratio. Note that even through the sample from the chilled margin has lower velocities, its $\mathrm{V}_{p}$ ' $\mathrm{V}_{s}$ ratio is similar to those of the other dike rocks. A velocitydensity plot at $100 \mathrm{MPa}$ for sheeted dikes drilled on DSDP Leg 83 and ODP Leg 111 is given in Figure 4. The linear and nonlinear curves are those of Christensen and Salisbury (1975) for the DSDP basalts, and the nonlinear curve is required to fit the data. The velocities obtained from the Leg 111 samples are clearly higher than those of Leg 83 .

Average laboratory-measured velocities, densities, and porosities of the Leg 111 samples are given in Table 2, which also includes previous Hole 504B data (Christensen and Salisbury, 
Table 1. Compressional- and shear-wave velocities and elastic constants of samples of Hole 504B sheeted dike rocks.

\begin{tabular}{|c|c|c|c|c|c|c|c|}
\hline $\begin{array}{l}\text { Core, section, } \\
\text { interval }(\mathrm{cm})\end{array}$ & $\begin{array}{l}\text { Pressure } \\
\text { (kb) }\end{array}$ & $\begin{array}{c}\mathrm{V}_{p} \\
(\mathrm{~km} / \mathrm{s})\end{array}$ & $\begin{array}{c}\mathrm{V}_{\mathrm{s}} \\
(\mathrm{km} / \mathrm{s})\end{array}$ & $\mathrm{V}_{p} / \mathrm{V}_{s}$ & $\begin{array}{l}\text { Poisson's } \\
\text { ratio }\end{array}$ & $\begin{array}{c}\text { Bulk } \\
\text { modulus } \\
(\mathrm{Mb})\end{array}$ & $\begin{array}{c}\text { Shear } \\
\text { modulus } \\
(\mathrm{Mb})\end{array}$ \\
\hline $142 \mathrm{R}-2,60-62$ & 0.2 & 6.48 & 3.55 & 1.82 & 0.28 & 0.75 & 0.38 \\
\hline$\rho=2.98 \mathrm{~g} / \mathrm{cm}^{3}$ & 0.4 & 6.55 & 3.58 & 1.83 & 0.29 & 0.77 & 0.38 \\
\hline \multirow[t]{6}{*}{$\phi=0.2 \%$} & 0.6 & 6.60 & 3.60 & 1.83 & 0.29 & 0.78 & 0.39 \\
\hline & 0.8 & 6.63 & 3.61 & 1.84 & 0.30 & 0.79 & 0.39 \\
\hline & 1.0 & 6.66 & 3.62 & 1.84 & 0.29 & 0.80 & 0.39 \\
\hline & 2.0 & 6.74 & 3.66 & 1.84 & 0.29 & 0.82 & 0.40 \\
\hline & 4.0 & 6.82 & 3.70 & 1.84 & 0.29 & 0.84 & 0.41 \\
\hline & 6.0 & 6.87 & 3.73 & 1.84 & 0.29 & 0.86 & 0.42 \\
\hline $145 \mathrm{R}-2,126-128$ & 0.2 & 6.29 & 3.53 & 1.78 & 0.27 & 0.68 & 0.37 \\
\hline$\rho=2.94 \mathrm{~g} / \mathrm{cm}^{3}$ & 0.4 & 6.54 & 3.60 & 1.82 & 0.28 & 0.75 & 0.38 \\
\hline \multirow[t]{6}{*}{$\phi=0.7 \%$} & 0.6 & 6.64 & 3.64 & 1.82 & 0.28 & 0.78 & 0.39 \\
\hline & 0.8 & 6.69 & 3.67 & 1.82 & 0.28 & 0.79 & 0.40 \\
\hline & 1.0 & 6.71 & 3.69 & 1.82 & 0.28 & 0.79 & 0.40 \\
\hline & 2.0 & 6.76 & 3.76 & 1.80 & 0.28 & 0.79 & 0.42 \\
\hline & 4.0 & 6.81 & 3.80 & 1.79 & 0.27 & 0.80 & 0.43 \\
\hline & 6.0 & 6.84 & 3.82 & 1.79 & 0.27 & 0.80 & 0.43 \\
\hline $145 \mathrm{R}-2,139-141$ & 0.2 & 6.34 & 3.51 & 1.81 & 0.28 & 0.71 & 0.37 \\
\hline$\rho=2.98 \mathrm{~g} / \mathrm{cm}^{3}$ & 0.4 & 6.54 & 3.59 & 1.82 & 0.28 & 0.76 & 0.38 \\
\hline \multirow[t]{6}{*}{$\phi=0.3 \%$} & 0.6 & 6.64 & 3.64 & 1.82 & 0.28 & 0.78 & 0.39 \\
\hline & 0.8 & 6.69 & 3.67 & 1.82 & 0.28 & 0.80 & 0.40 \\
\hline & 1.0 & 6.73 & 3.69 & 1.82 & 0.28 & 0.81 & 0.41 \\
\hline & 2.0 & 6.82 & 3.74 & 1.82 & 0.28 & 0.83 & 0.42 \\
\hline & 4.0 & 6.91 & 3.77 & 1.83 & 0.29 & 0.86 & 0.42 \\
\hline & 6.0 & 6.96 & 3.79 & 1.84 & 0.29 & 0.87 & 0.43 \\
\hline $148 \mathrm{R}-1,50-52$ & 0.2 & 6.17 & 3.40 & 1.81 & 0.28 & 0.68 & 0.35 \\
\hline \multirow[t]{6}{*}{$\phi=0.2 \%$} & 0.6 & 6.61 & 3.59 & 1.84 & 0.29 & 0.80 & 0.39 \\
\hline & 0.8 & 6.67 & 3.63 & 1.84 & 0.29 & 0.81 & 0.40 \\
\hline & 1.0 & 6.71 & 3.65 & 1.84 & 0.29 & 0.82 & 0.40 \\
\hline & 2.0 & 6.78 & 3.71 & 1.83 & 0.29 & 0.83 & 0.42 \\
\hline & 4.0 & 6.84 & 3.76 & 1.82 & 0.28 & 0.84 & 0.43 \\
\hline & 6.0 & 6.88 & 3.79 & 1.82 & 0.28 & 0.85 & 0.43 \\
\hline${ }^{a} 152 R-1,50-52$ & 0.2 & 6.28 & 3.43 & 1.83 & 0.29 & 0.70 & 0.35 \\
\hline$\rho=2.95 \mathrm{~g} / \mathrm{cm}^{3}$ & 0.4 & 6.38 & 3.48 & 1.83 & 0.29 & 0.72 & 0.36 \\
\hline \multirow[t]{6}{*}{$\phi=0.2 \%$} & 0.6 & 6.43 & 3.52 & 1.83 & 0.29 & 0.73 & 0.36 \\
\hline & 0.8 & 6.47 & 3.54 & 1.83 & 0.29 & 0.74 & 0.37 \\
\hline & 1.0 & 6.49 & 3.57 & 1.82 & 0.28 & 0.74 & 0.38 \\
\hline & 2.0 & 6.56 & 3.62 & 1.81 & 0.28 & 0.76 & 0.39 \\
\hline & 4.0 & 6.62 & 3.66 & 1.81 & 0.28 & 0.77 & 0.40 \\
\hline & 6.0 & 6.66 & 3.67 & 1.81 & 0.28 & 0.78 & 0.40 \\
\hline $155 \mathrm{R}-1,67-69$ & 0.2 & 6.32 & 3.44 & 1.84 & 0.29 & 0.73 & 0.36 \\
\hline$\rho=3.00 \mathrm{~g} / \mathrm{cm}^{3}$ & 0.4 & 6.50 & 3.52 & 1.85 & 0.29 & 0.77 & 0.37 \\
\hline \multirow[t]{6}{*}{$\phi=0.2 \%$} & 0.6 & 6.58 & 3.57 & 1.84 & 0.29 & 0.79 & 0.38 \\
\hline & 0.8 & 6.63 & 3.61 & 1.84 & 0.29 & 0.80 & 0.39 \\
\hline & 1.0 & 6.67 & 3.63 & 1.84 & 0.29 & 0.81 & 0.40 \\
\hline & 2.0 & 6.76 & 3.70 & 1.83 & 0.29 & 0.82 & 0.41 \\
\hline & 4.0 & 6.85 & 3.75 & 1.83 & 0.29 & 0.85 & 0.42 \\
\hline & 6.0 & 6.90 & 3.77 & 1.83 & 0.29 & 0.86 & 0.43 \\
\hline $161 \mathrm{R}-1,17-19$ & 0.2 & 6.47 & 3.48 & 1.86 & 0.30 & 0.76 & 0.36 \\
\hline$\rho=2.96 \mathrm{~g} / \mathrm{cm}^{3}$ & 0.4 & 6.57 & 3.56 & 1.85 & 0.29 & 0.78 & 0.38 \\
\hline \multirow[t]{6}{*}{$\phi=0.3 \%$} & 0.6 & 6.64 & 3.60 & 1.84 & 0.29 & 0.80 & 0.38 \\
\hline & 0.8 & 6.70 & 3.64 & 1.84 & 0.29 & 0.81 & 0.39 \\
\hline & 1.0 & 6.74 & 3.66 & 1.84 & 0.29 & 0.82 & 0.40 \\
\hline & 2.0 & 6.83 & 3.72 & 1.84 & 0.29 & 0.84 & 0.41 \\
\hline & 4.0 & 6.88 & 3.76 & 1.83 & 0.29 & 0.84 & 0.42 \\
\hline & 6.0 & 6.89 & 3.79 & 1.82 & 0.28 & 0.84 & 0.43 \\
\hline $163 \mathrm{R}-1,68-70$ & 0.2 & 6.41 & 3.51 & 1.83 & 0.29 & 0.73 & 0.36 \\
\hline$\rho=2.96 \mathrm{~g} / \mathrm{cm}^{3}$ & 0.4 & 6.54 & 3.57 & 1.83 & 0.29 & 0.76 & 0.38 \\
\hline \multirow[t]{6}{*}{$\phi=0.5 \%$} & 0.6 & 6.61 & 3.62 & 1.83 & 0.29 & 0.78 & 0.39 \\
\hline & 0.8 & 6.65 & 3.65 & 1.82 & 0.28 & 0.79 & 0.39 \\
\hline & 1.0 & 6.69 & 3.67 & 1.82 & 0.28 & 0.79 & 0.40 \\
\hline & 2.0 & 6.77 & 3.73 & 1.82 & 0.28 & 0.81 & 0.41 \\
\hline & 4.0 & 6.85 & 3.76 & 1.82 & 0.28 & 0.83 & 0.42 \\
\hline & 6.0 & 6.90 & 3.78 & 1.83 & 0.29 & 0.85 & 0.42 \\
\hline
\end{tabular}

a Chilled margin.

1985). Linear regressions of $\mathrm{V}_{p}, \mathrm{~V}_{s}$, and bulk density $(\rho)$ as functions of depth give the following:

$$
\begin{array}{ll}
\mathrm{V}_{p}=6.00 \mathrm{~km} / \mathrm{s}+0.43 \mathrm{z} / \mathrm{s} & r=0.62 \\
\mathrm{~V}_{\mathrm{s}}=3.21 \mathrm{~km} / \mathrm{s}+0.26 \mathrm{z} / \mathrm{s} & r=0.62 \\
\rho=(2.83+0.11 \mathrm{z} / \mathrm{km}) \mathrm{g} / \mathrm{cm}^{3} & r=0.73,
\end{array}
$$

where $z$ is the depth in kilometers and $r$ is the correlation coefficient. Thus, the general increase of velocities and bulk densities with depth, independent of overburden pressure, is due to increasing metamorphic grade and decreasing porosity with depth. The latter is borne out by downhole porosity (Becker, 1985) and permeability (Anderson et al., 1985) measurements. 


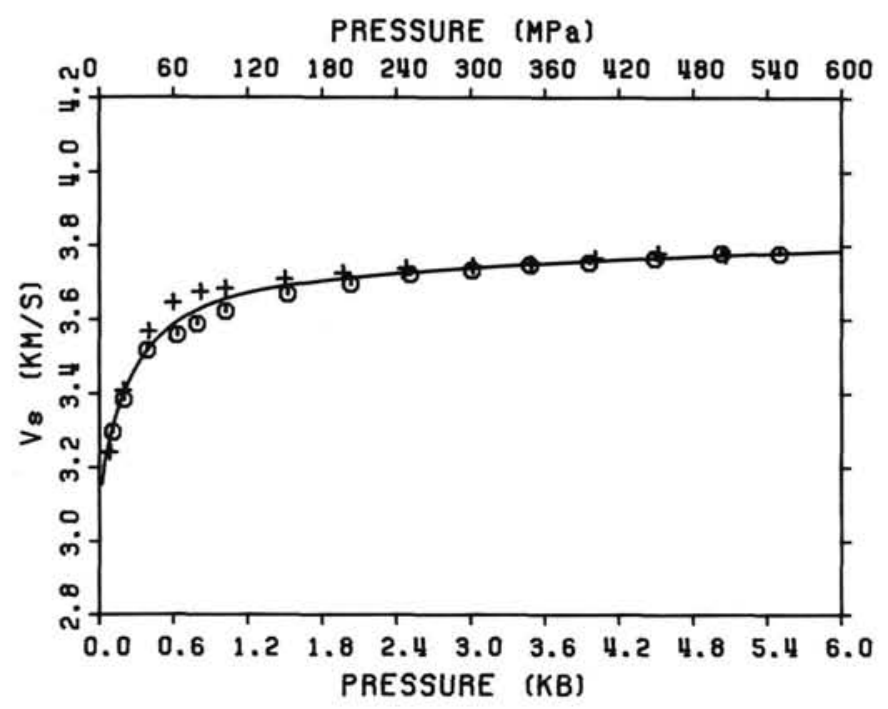

Figure 1. $V_{s}$ as a function of pressure for dike Sample 111-504B-148R-1, $50-52 \mathrm{~cm}$. Circles and pluses are velocities measured while the pressure increased and decreased, respectively. The curve fit is from Wepfer and Christensen (1987).

Ophiolites are believed to be onshore exposures of ocean crust, so laboratory velocity and density data from Hole 504B dike rocks should compare favorably with those obtained in ophiolite studies. In Figure 5, velocities at $100 \mathrm{MPa}$ confining pressure (appropriate for a depth of approximately $2 \mathrm{~km}$ below the seafloor) and densities of the Hole 504B dike rocks are compared with similar data for dikes from ophiolites. Several trends are evident in the Figure 6 plot of $\mathrm{V}_{p}$ vs. $\mathrm{V}_{s}$ for the same samples:

1. The velocities of the Hole 504B dike rocks ( $\mathrm{V}_{p}$ from 6.2 to $6.7 \mathrm{~km} / \mathrm{s}$ and $\mathrm{V}_{s}$ from 3.15 to $3.75 \mathrm{~km} / \mathrm{s}$ ) match the high ophiolite velocities.

2. The velocity ratios of the ophiolite and Hole 504B dike rocks are similar.

3. The range of velocities measured for the Hole 504B dike rocks is much smaller than that found for the corresponding ophiolite rocks.

4. The velocity-density systematics of the Hole 504B dike rocks are quite different from those of the ophiolites (Fig. 5). For given compressional- or shear-wave velocities, the densities of the Hole 504B dike rocks tend to be higher than the ophiolite densities, resulting in fairly distinct clusters of Hole 504B points on the Figure 5 velocity-density plots. Chemical analyses and petrographic studies of thin sections provide insight on the origin of this observation. Birch (1961) showed that $V_{p}$ is a function of density and mean atomic weight and that, in general, for a constant velocity, lower mean atomic weights correspond to lower densities. A similar relationship was found for $\mathrm{V}_{s}$ by Christensen (1968). Average mean atomic weights calculated from chemical analyses of Bay of Islands, Samail, and Hole 504B dike rocks are summarized in Table 3. The mean atomic weights of the Bay of Islands rocks are similar to those of Hole 504B. However, some of the velocity-density differences between the Hole 504B and Samail dike rocks apparently are related to chemical variations.

Comparisons of Leg 111 dike petrography with that of the ophiolite dike rocks show that even though at a given depth the metamorphic grades are similar, the ophiolites commonly contain higher percentages of metamorphic minerals. In the higher-

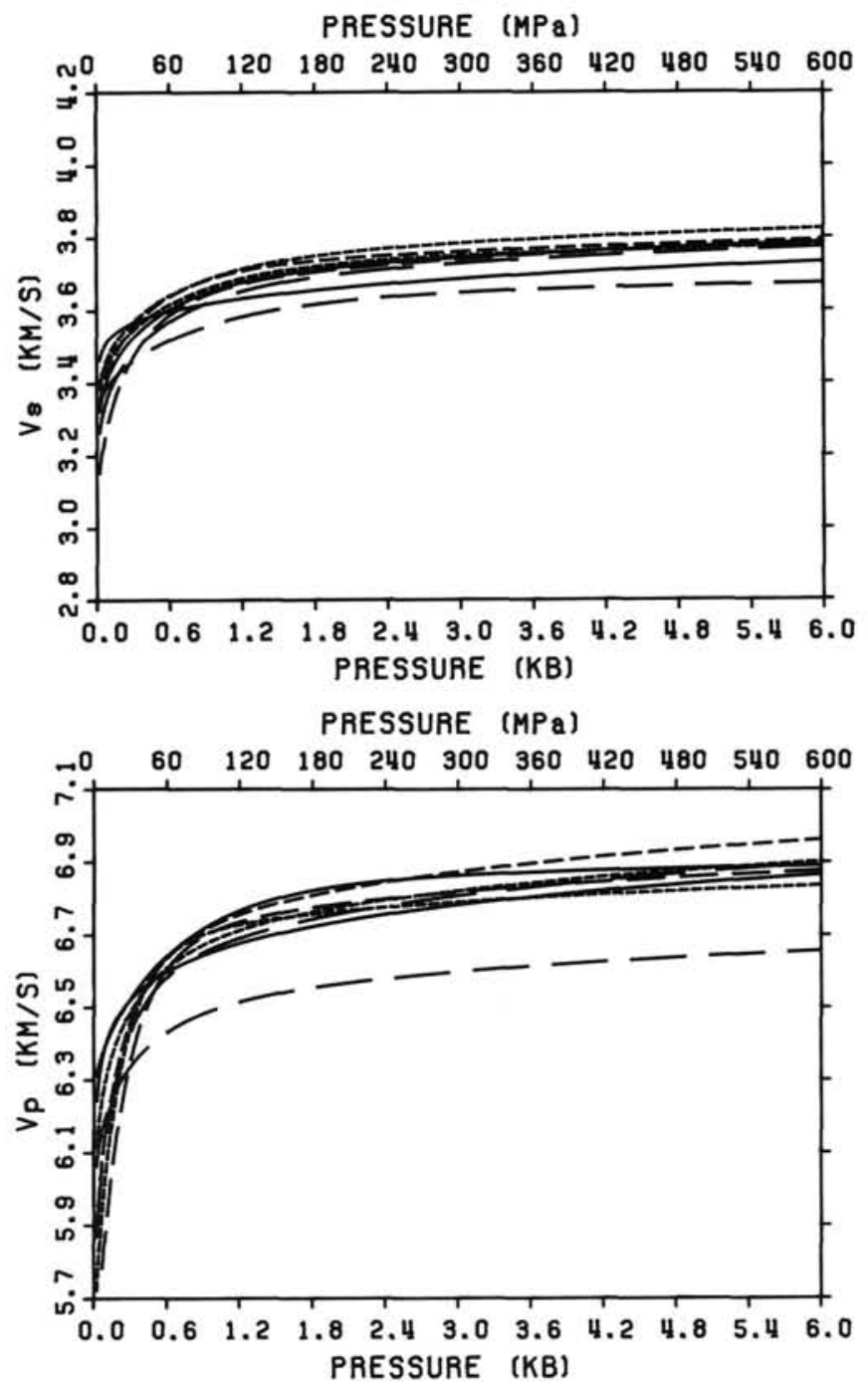

Figure 2. $\mathrm{V}_{p}$ and $\mathrm{V}_{s}$ as a function of pressure for samples of the Leg 111 dike rocks. Data points are omitted to avoid clutter. The sample with the lowest velocities (111-504B-152R-1, 50-52 cm) is from the vicinity of a chilled margin.

level ophiolite dike rocks, this alteration-along with relatively high porosity-has greatly lowered velocities. The abundant chlorite and actinolite in the lower ophiolite dike rocks apparently decreases bulk densities without reducing velocities. The greater abundances of secondary minerals in the ophiolite dike rocks can be explained by differences in the spreading rate. The metamorphism of dike rocks is probably related to high heat flow on the ridges before the crust moves to cooler flanks. Oceanic crust generated at rapidly accreting ridges will thus have less thermal and hydrothermal metamorphism than crust produced at slowly accreting ridges (Dewey and Bird, 1971). The estimated spreading rate at Site 504 is rather high (Klitgord and Mudie, 1974), which is consistent with the observation of relatively unaltered dike rocks at Hole 504B.

\section{CONCLUSIONS}

Compressional- and shear-wave velocities measured at elevated confining pressures are found to be higher for the sheeted dike rocks than the previously studied pillows and massive basalts at Hole 504B. A single glassy sample, however, indicates reduced velocities near chilled margins. The $\mathrm{V}_{p} / \mathrm{V}_{s}$ ratios and 


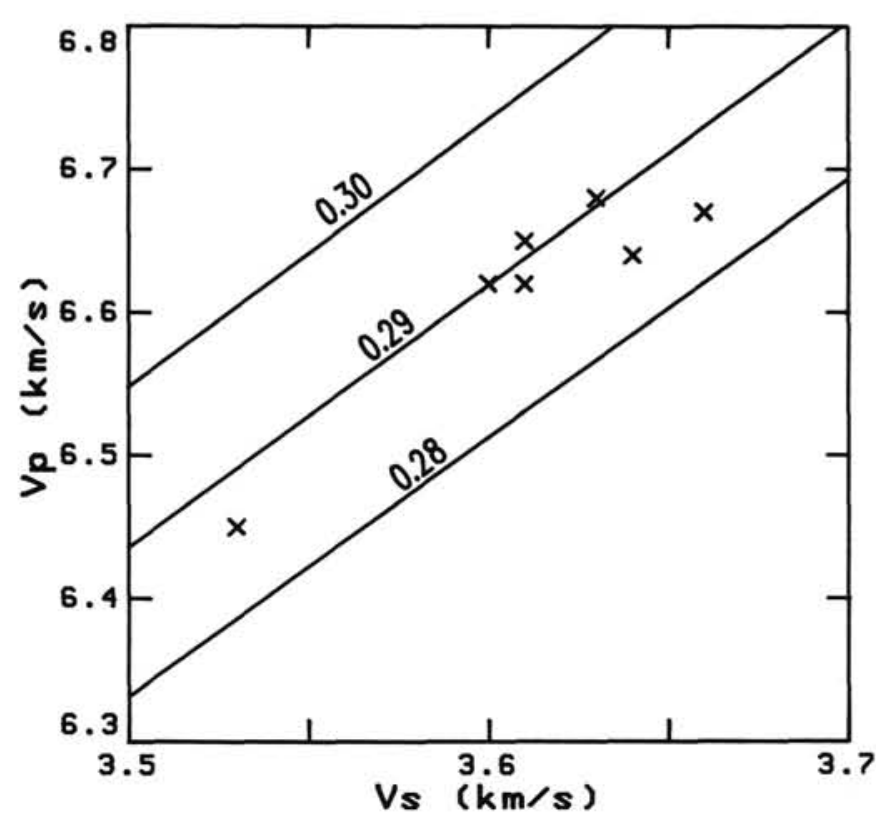

Figure 3. $\mathrm{V}_{p}$ vs. $\mathrm{V}_{s}$ for Leg 111 samples at in-situ pressures. Lines of constant Poisson's ratio are indicated.

elastic constants of the dike samples are similar to those of the overlying basalts, and an intrinsic increase in velocity and density with depth is the result of decreasing porosity and increasing metamorphic grade with depth. The relationship between velocity and metamorphic grade is complex, because some minerals lower velocities whereas other raise velocities.

Laboratory-measured velocities of the Hole 504B dike rocks are found to be similar to those from ophiolite sheeted dikes. Plots of $\mathrm{V}_{p}$ and $\mathrm{V}_{s}$ vs. density, however, reveal distinct differences between the Hole 504B and ophiolite samples. For a given velocity, Hole 504B dike samples have a higher density. This may be due in part to differences in chemistry, but also results from a lower concentration of metamorphic minerals in the Hole 504B rocks. This is explained by the formation of Hole 504B sheeted dikes at a fast spreading center which did not provide adequate time for extensive metamorphism to occur.

\section{ACKNOWLEDGMENTS}

The laboratory studies were supported by the Office of Naval Research contract N-00014-84-K-0207.

\section{REFERENCES}

Anderson, R. N., Honnorez, J., Becker, K., et al., 1985. Init. Repts. DSDP, 83: Washington (U.S. Govt. Printing Office).

Anderson, R. N., Zoback, M. D., Hickman, S. H., and Newmark, R. L., 1985. Permeability versus depth in the upper oceanic crust: in situ measurements in Deep Sea Drilling Project Hole 504B, eastern equatorial Pacific. In Anderson, R. N., Honnorez, J., Becker, K., et al., Init. Repts. DSDP, 83: Washington (U.S. Govt. Printing Office), 429-442.

Becker, K., 1985. Large-scale electrical resistivity and bulk porosity of the oceanic crust, Deep Sea Drilling Project Hole 504B, Costa Rica Rift. In Anderson, R. N., Honnorez, J., Becker, K., et al., Init. Repts. DSDP, 83: Washington (U.S. Govt. Printing Office), 419427.

Birch, F., 1960. The velocity of compressional waves in rocks to 10 kilobars, 1. J. Geophys. Res., 65:1083-1102.

1961. The velocity of compressional waves in rocks to $10 \mathrm{ki}-$ lobars, 2. J. Geophys. Res., 66:2199-2224.

Christensen, N. I., 1968. Chemical changes associated with upper mantle structure. Tectonophysics, 6:331-342.

1984. Pore pressure and oceanic crustal seismic structure. Geophys. J. R. Astron. Soc., 79:411-424.

Christensen, N. I., and Salisbury, M. H., 1975. Structure and constitution of the lower oceanic crust. Rev. Geophys. Space Phys., 13:5786.

1982. Lateral heterogeneity in the seismic structure of the oceanic crust inferred from velocity studies in the Bay of Islands ophiolite, Newfoundland. Geophys. J. R. Astron. Soc., 68:675-688. 1985. Seismic velocities, densities, and porosities of Layer 2B and Layer $2 \mathrm{C}$ basalts from Hole 504B. In Anderson, R. N., Honnorez, J., Becker, K., et al., Init. Repts. DSDP, 83: Washington (U.S. Govt. Printing Office), 367-370.

Christensen, N. I., and Smewing, J. D., 1981. Geology and seismic structure of the northern section of the Oman ophiolite. J. Geophys. Res., 86:2545-2556.

Christensen, N. I., and Wilkens, R. H., 1982. Seismic properties, density, and composition of the Icelandic crust near Reydarfjordur. $J$. Geophys. Res., 87:6389-6395.

Dewey, J. F., and Bird, J. M., 1971. Origin and emplacement of the ophiolite suite: Appalachian ophiolites in Newfoundland. J. Geophys. Res., 76:3179-3206.

Kempner, W. C., and Gettrust, J. F., 1982. Ophiolites, synthetic seismograms and ocean crustal structure, 1. Comparison of ocean bottom seismometer data and synthetic seismograms for the Bay of Islands ophiolite. J. Geophys Res., 87:8447-8462.

Klitgord, K. D., and Mudie, J. D., 1974. The Galapagos spreading centre: a near-bottom geophysical survey. Geophys. J. R. Astron. Soc., 38:563-586.

Raitt, R. W., 1963. The crustal rocks. In Hill, M. N. (Ed.), The Sea (vol. 3): New York (Wiley), 85-102.

Salisbury, M. H., and Christensen, N. I., 1978. The seismic velocity structure of a traverse through the Bay of Islands Ophiolite Complex, Newfoundland, an exposure of oceanic crust and upper mantle. J. Geophys. Res., 83:805-817.

Salisbury, M. H., Christensen, N. I., Becker, K., and Moos, D., 1985. The velocity structure of Layer 2 at Deep Sea Drilling Project Site 504B from logging and laboratory measurements. In Anderson, R. N., Honnorez, J., Becker, K., et al. Init. Repts. DSDP, 83: Washington (U.S. Govt. Printing Office), 529-539.

Wepfer, W. W., and Christensen, N. I., 1987. Characterizing microcracks via a velocity-pressure relation. EOS, Trans. Am. Geophys. Union, 68:1503.

Date of initial receipt: 20 June 1988

Date of acceptance: 6 February 1989

Ms 111B-153 

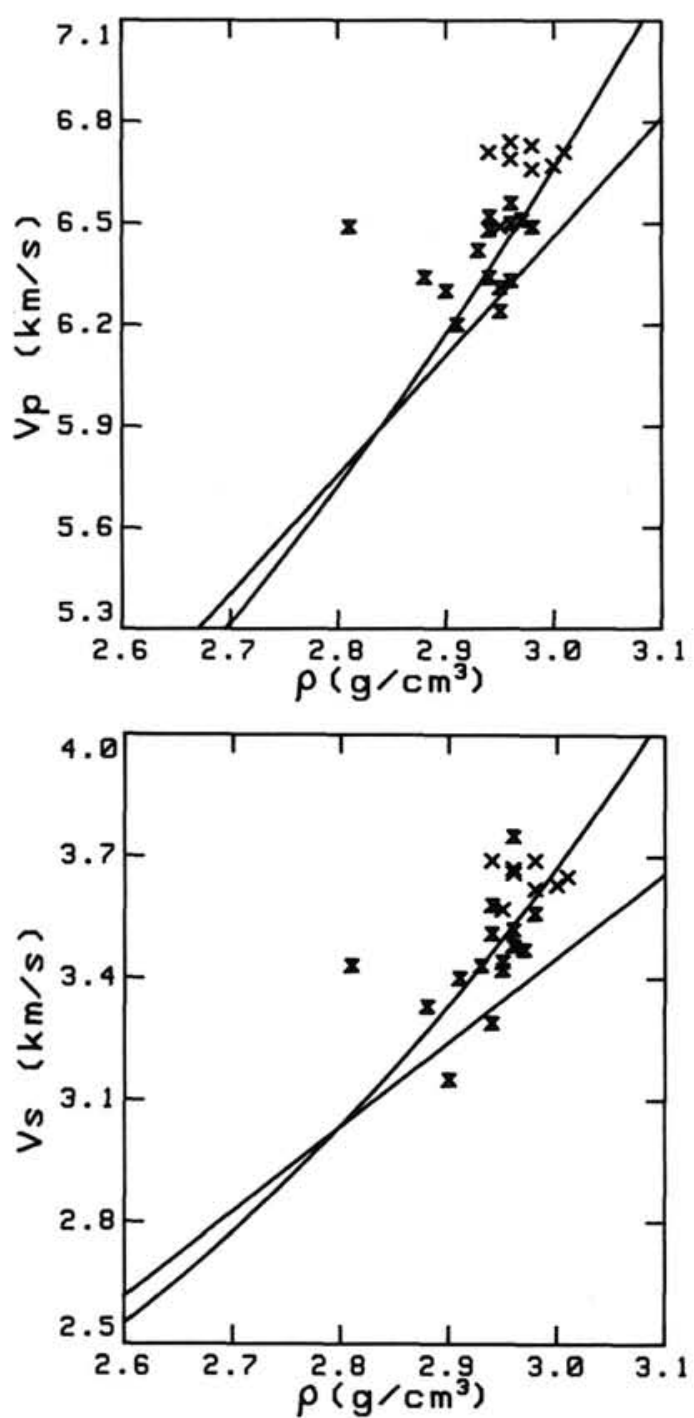

Figure 4. $\mathrm{V}_{p}$ and $\mathrm{V}_{s}$ as a function of density for Leg 111 (crosses) and Leg 83 (bow ties) dike rocks at $100 \mathrm{MPa}$. The linear and nonlinear curves are from Christensen and Salisbury (1975).
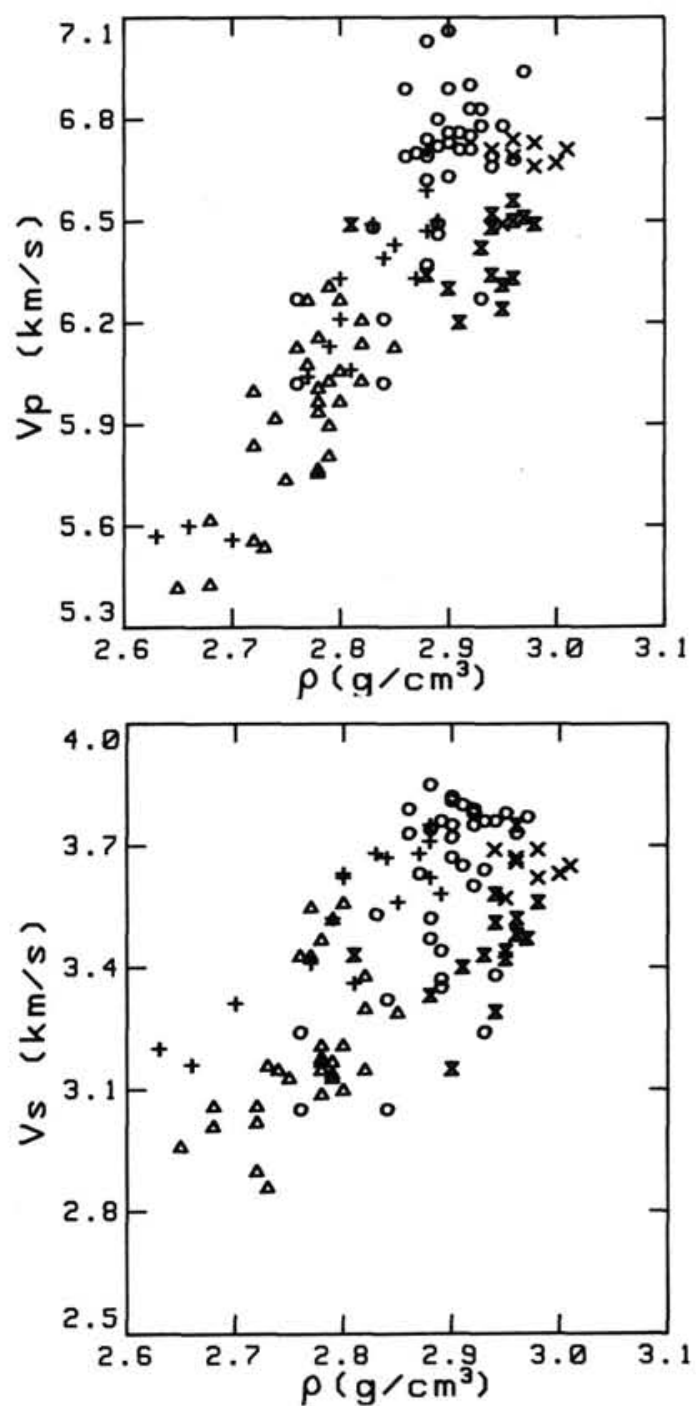

Figure 5. $\mathrm{V}_{p}$ and $\mathrm{V}_{s}$ at $100 \mathrm{MPa}$ vs. density for dike rocks from Leg 111 (crosses), Leg 83 (bow ties), Bay of Islands ophiolite (Christensen and Salisbury, 1982) (circles), Samail ophiolite (Christensen and Smewing, 1981) (triangles), and Troodos ophiolite (N. I. Christensen, unpubl. data) (pluses).

Table 2. Averaged laboratory measurements Hole 504B basalts.

\begin{tabular}{ccccccc}
\hline \multicolumn{1}{c}{$\begin{array}{c}\text { Core } \\
\text { interval }\end{array}$} & $\begin{array}{c}\text { Depth } \\
\text { within } \\
\text { basement } \\
(\mathrm{m})\end{array}$ & $\begin{array}{c}\text { Number } \\
\text { of } \\
\text { samples }\end{array}$ & $\begin{array}{c}\mathrm{V}_{p} \\
(\mathrm{~km} / \mathrm{s})\end{array}$ & $\begin{array}{c}\mathrm{V}_{s} \\
(\mathrm{~km} / \mathrm{s})\end{array}$ & $\begin{array}{c}\text { Bulk } \\
\text { density } \\
\left(\mathrm{g} / \mathrm{cm}^{3}\right)\end{array}$ & $\begin{array}{c}\text { Porosity } \\
(\%)\end{array}$ \\
\hline $3-8$ & 28 & 4 & 6.26 & 3.32 & 2.86 & 1.7 \\
$9-15$ & 80 & 4 & 6.12 & 3.32 & 2.88 & 2.1 \\
$16-23$ & 142 & 4 & 6.14 & 3.31 & 2.86 & 1.7 \\
$24-33$ & 212 & 4 & 6.13 & 3.33 & 2.87 & 2.2 \\
$34-45$ & 303 & 4 & 5.85 & 3.15 & 2.77 & 5.8 \\
$46-60$ & 415 & 3 & 6.43 & 3.47 & 2.93 & 1.3 \\
$61-71$ & 519 & 2 & 5.98 & 3.18 & 2.86 & 2.4 \\
$72-77$ & 592 & 4 & 6.07 & 3.24 & 2.88 & 1.2 \\
$78-83$ & 648 & 4 & 5.79 & 3.09 & 2.83 & 4.5 \\
$84-89$ & 696 & 4 & 6.28 & 3.39 & 2.93 & 1.3 \\
$90-95$ & 747 & 4 & 6.45 & 3.50 & 2.94 & 1.1 \\
$96-105$ & 817 & 4 & 6.45 & 3.41 & 2.92 & 0.8 \\
$106-124$ & 913 & 6 & 6.24 & 3.40 & 2.93 & 1.0 \\
$125-130$ & 990 & 4 & 6.44 & 3.46 & 2.95 & 0.4 \\
$131-138$ & 1038 & 4 & 6.46 & 3.50 & 2.94 & 0.5 \\
$139-150 \mathrm{R}$ & 1114 & 4 & 6.70 & 3.67 & 2.98 & 0.3 \\
$151 \mathrm{R}-163 \mathrm{R}$ & 1205 & 4 & 6.65 & 3.63 & 2.97 & 0.3 \\
\hline
\end{tabular}


N. I. CHRISTENSEN, W, W. WEPFER, R. D. BAUD

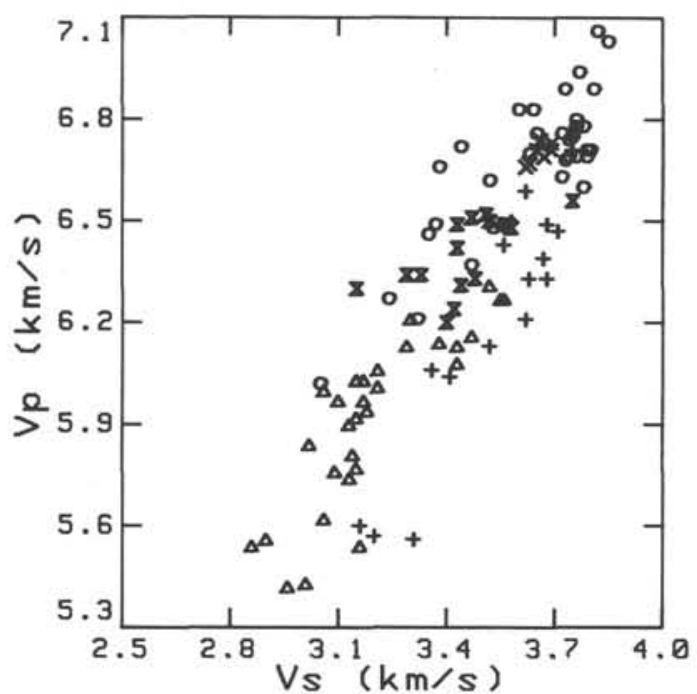

Table 3. Mean atomic weights for sheeted dikes.

\begin{tabular}{llll}
\hline Location & Oman & Bay of Islands & Hole 504B \\
Number of samples & 9 & 11 & 7 \\
Mean atomic weight & $21.85 \pm 0.21$ & $22.12 \pm 0.21$ & $22.14 \pm 0.20$
\end{tabular}

Figure 6. $\mathrm{V}_{p}$ vs. $\mathrm{V}_{s}$ for Hole $504 \mathrm{~B}$ and ophiolite dike rocks at $100 \mathrm{MPa}$ (same symbols as Fig. 5). 